\title{
Time of Onset of Selected Skin Lesions Associated with COVID-19: A Systematic Review
}

\author{
Paolo Gisondi (D) - Sara Di Leo · Francesco Bellinato · Simone Cazzaniga • \\ Stefano Piaserico $\cdot$ Luigi Naldi
}

Received: March 3, 2021 / Published online: April 2, 2021

(C) The Author(s) 2021

\section{ABSTRACT}

Introduction: Distinct skin lesions associated with coronavirus disease 2019 (COVID-19) have been described, but data regarding their time of onset during the COVID-19 course are scant. Our objective was to systematically review the studies reporting the time of onset of selected skin lesions with respect to the reported onset of the COVID-19 core symptoms.

Methods: A comprehensive search of studies published before 21 January 2021 was

Supplementary Information The online version contains supplementary material available at https:// doi.org/10.1007/s13555-021-00526-8.

P. Gisondi $(\bowtie) \cdot F$. Bellinato

Section of Dermatology and Venereology,

Department of Medicine, University of Verona,

Verona, Italy

e-mail: paolo.gisondi@univr.it

S. Di Leo $\cdot$ L. Naldi

Division of Dermatology, San Bortolo Hospital,

Vicenza, Italy

S. Cazzaniga $\cdot$ L. Naldi

Centro Studi GISED, Bergamo, Italy

S. Cazzaniga

Department of Dermatology, Inselspital University

Hospital of Bern, Bern, Switzerland

S. Piaserico

Section of Dermatology, Department of Medicine,

University of Padua, Padua, Italy performed on MEDLINE via PubMed database using a predefined strategy to identify relevant articles.

Results: Out of 354 references, 87 were selected, reporting a total of 895 patients with skin lesions associated with COVID-19. The most frequent pattern was exanthema $(n=430$, $48 \%)$, followed by vascular $(n=299,33 \%)$, urticarial $(n=105,12 \%)$ and others $(n=66$, $7 \%)$. Skin lesions occurred more frequently in the first 4 weeks from the COVID-19 onset $(n=831,92 \%)$, whereas prodromal or late lesions were rarer $(n=69,8 \%)$. The urticarial and exanthema patterns were more frequent in the first 2 weeks. About the vascular pattern some differences were noted among its subtypes. Livedoid lesions occurred mainly in the first 2 weeks, while chilblain-like lesions between weeks 2 and 4 . Purpuric/petechial lesions were equally distributed during the first 4 weeks. Several skin manifestations did not fall into the pattern classification, including erythema multiforme, generalized pruritus, Kawasaki disease and others.

Conclusion: The diversity in the time of onset of skin lesions as well as their polymorphic nature likely reflects the diversity of the pathogenetic underlying mechanisms.

PROSPERO database registration
number: CRD42021236331.

Keywords: Chilblain; COVID-19; Livedo; Purpura; SARS-CoV-2; Urticaria; Varicella; Weal 


\section{Key Summary Points}

The most frequent patterns of skin manifestations associated with COVID-19 were exanthema, followed by vascular and urticarial lesions.

Skin lesions occurred more frequently during the first 4 weeks after COVID-19 onset, whereas prodromal or late sequelae were rarer.

The diversity in the time of onset of skin lesions as well as their polymorphic nature likely reflects the diversity of the pathogenetic underlying mechanisms.

\section{DIGITAL FEATURES}

This article is published with digital features, including a summary slide, to facilitate understanding of the article. To view digital features for this article, go to https://doi.org/10.6084/ m9.figshare.14319707.

\section{INTRODUCTION}

Although coronavirus disease 2019 (COVID-19) is best known for causing fever and respiratory symptoms, it is also associated with different extrapulmonary manifestations $[1,2]$. A population-based framework of the spectrum of different manifestations associated with severe acute respiratory syndrome coronavirus 2 (SARS-CoV-2) infection has been proposed recently by Datta SD et al., who describes three main phases of the disease: acute (within 2 weeks of the COVID-19 onset), post-acute (week 2-4) and late (after week 4) [3]. The acute phase is clinically characterized by the core COVID-19 symptoms related to active viral replication and initial host response including fever, cough, dyspnoea, myalgia, headache, anosmia and dysgeusia; the post-acute phase is driven by the hyperinflammatory illness leading to gastrointestinal, cardiovascular, respiratory, neurological, musculoskeletal and mucocutaneous symptoms; the late phase is associated with cardiovascular, pulmonary, neurological and psychological sequelae [4]. Dermatologic manifestations associated with SARS-CoV-2 infection are polymorphic, and they have been classified in distinct patterns, including the exanthema (varicella-like or papulo-vesicular, and morbilliform rash), vascular (chilblain-like, purpuric/petechial and livedoid lesions) and urticarial pattern (Fig. 1) $[5,6]$. Although there is a growing literature amplifying the current knowledge on their clinical features, pathophysiological mechanisms and therapeutic management, data on their time of onset during the course of COVID19 are scant. The objective of this study is to systematically review the studies reporting the time of onset of selected skin lesions with respect to the beginning of the reported onset of the COVID-19 core symptoms.
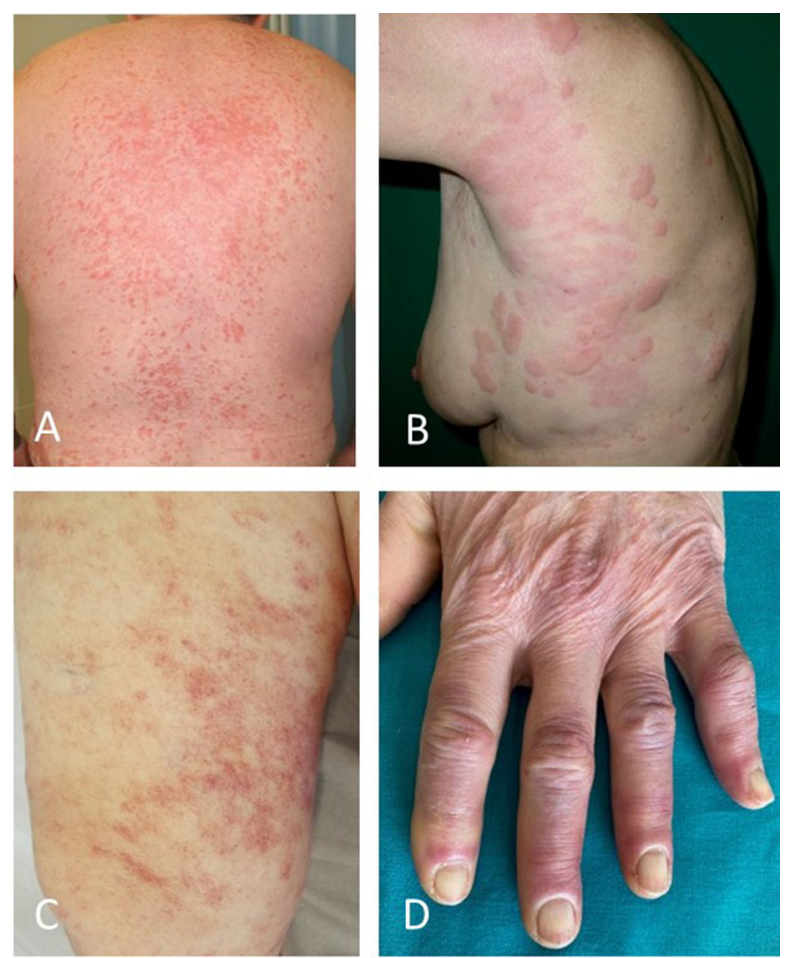

Fig. 1 Selected skin lesions associated with COVID-19; a morbilliform rush in the back; $\mathbf{b}$ urticarial lesions in the chest; c purpuric lesions in the thigh; $\mathbf{d}$ chilblain like lesions in the hand 


\section{METHODS}

\section{Search Strategy}

The study was designed according to Preferred Reporting Items for Systematic Reviews and Meta-Analyses (PRISMA) guidelines [7]. The protocol of the study was registered on PROSPERO database (registration number CRD42021236331). Electronic searches were performed on MEDLINE via PubMed database using the following key words: COVID-19, varicella, morbilliform, chilblain, erythema, acropapular, manifestation, lesion, sign, pattern, vesicular, purpuric, petechial, livedoid, weal. The exact string, combining the disease of interest and skin manifestations and its subtype/elementary lesion was as follows: (COVID19) AND (varicella* OR morbill* ${ }^{*}$ OR chilblain OR urticaria* OR erythem* OR acropapul*) AND (manifestation* OR lesion* OR sign* OR pattern* OR vesicul* OR purpuric OR petechial OR lived $^{*}$ OR weal*). Original articles published between 1 January 2020 and 21 January 2021 were included. References of the selected publications were additionally screened for other eligible records.

\section{Selection Criteria}

Eligible manuscripts included all the original studies reporting the time of onset of selected skin lesions with respect to the reported onset of the COVID-19 core symptoms (i.e. fever, cough, dyspnoea, myalgia, headache, anosmia and dysgeusia). Skin lesions were then classified in the following patterns: exanthema (varicellalike and morbilliform rash), vascular (chilblainlike, purpuric/petechial and livedoid lesions) and urticarial [4]. Skin lesions not falling within the previously mentioned patterns were classified as 'other'. According to the framework proposed by Datta SD et al., the time of onset of skin lesions was classified as acute (within 2 weeks of COVID-19 onset), post-acute (from week 2 to 4) or late (after week 4) [3]. We have additionally considered a prodromal phase in case skin lesions had been reported before COVID-19 onset, as the first symptom defining
SARS-CoV-2 infection. Non-eligible manuscripts included those not reporting the time of onset of skin lesions or written in a language other than English, expert opinion, literature reviews, meta-analyses and reply letters.

\section{Data Extraction}

Two blinded investigators (SDL, FB) independently extracted data by using an extraction form, and a third author (PG) was consulted to resolve any disagreement. Manuscripts were screened by title and abstract. References considered relevant were reviewed in full text and selected or rejected based on the inclusion and exclusion criteria. For each reference, the following features were considered: type of the study, number and gender of the patients, details of skin lesions and the time interval between their onset and the reported onset of the COVID-19 core symptoms (Supplementary Table 1). For each pattern, the number and proportion of cases occurring in the prodromal, acute, post-acute and late phase were estimated.

\section{Evaluation of Risk Bias}

The risk bias was assessed using the tool proposed by Murad et al. [8] Selection, ascertainment, causality and reporting domains were considered. The results of this tool were reported as an aggregate score (ranging from 0 to 8 ) as the sum of the scores of the eight binary responses . According to this tool, the average aggregate score across the studies was $4.41 \pm 0.49$ (Supplementary Table 2).

\section{Compliance with Ethics Guidelines}

This article is based on previously conducted studies and does not contain any studies with human participants or animals performed by any of the authors. The review adhered to the Preferred Reporting Items for Systematic Reviews and Meta-Analyses guidelines. This research has been conducted in accordance with the Helsinki Declaration. The participants provided consent for the images to be used in this publication. 


\section{RESULTS}

A total of 354 manuscripts were first identified through the electronic database search. Then, they were screened by title and abstract, and those deemed relevant $(n=260)$ were reviewed in full text and selected based on the inclusion and exclusion criteria. Finally, 87 original manuscripts [9-95] were analysed, and summarized in Table 1. All the articles were retrieved according to the algorithm shown in Fig. 2.

A total of 895 patients with skin lesions associated with COVID-19 were identified (5 patients presented two concomitant patterns). The most frequent pattern was exanthema $(n=430,48 \%)$, followed by vascular $(n=299$, $33 \%)$ and then urticarial $(n=105,12 \%)$. No acro-papular pattern was reported. Skin lesions occurred more frequently in the first 4 weeks

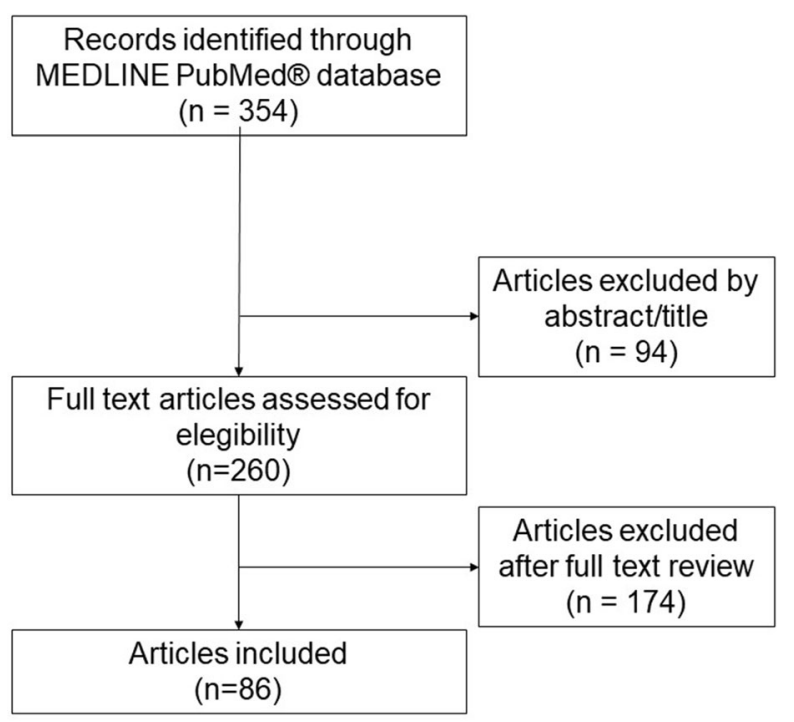

Fig. 2 Literature screening algorithm for articles included in the systematic review

Table 1 Time of onset of selected skin lesions with respect to the reported onset of the COVID-19 core symptoms

\begin{tabular}{|c|c|c|c|c|c|c|}
\hline Pattern & Skin lesions & Prodromal $^{\mathrm{a}}$ & $\begin{array}{l}\text { Week 0-2 } \\
\text { Acute }\end{array}$ & $\begin{array}{l}\text { Week 2-4 }{ }^{\mathrm{a}} \\
\text { Post-acute }\end{array}$ & $\begin{array}{l}\text { Week }>4^{a} \\
\text { Late sequelae }\end{array}$ & Total, $N(\%)$ \\
\hline \multirow[t]{2}{*}{ Exanthema } & Varicella-like papulo-vesicular & $12(8.8)$ & $86(63.2)$ & $36(26.5)$ & $2(1.5)$ & $136(15.1)$ \\
\hline & Morbilliform rash & $12(4.1)$ & $167(56.8)$ & $113(38.4)$ & $2(0.7)$ & $294(32.7)$ \\
\hline \multirow[t]{3}{*}{ Vascular } & Chilblain-like & $10(4.4)$ & $46(20.1)$ & $172(75.1)$ & $1(0.4)$ & $229(33.2)$ \\
\hline & Purpuric/petechial lesions & $0(0)$ & $13(43.3)$ & $17(56.7)$ & $0(0)$ & $30(3.3)$ \\
\hline & Livedoid lesions & $1(2.5)$ & $27(67.5)$ & $11(27.5)$ & $1(2.5)$ & $40(4.4)$ \\
\hline Urticaria & Weal & $17(16.1)$ & $83(79)$ & $4(3.9)$ & $1(1)$ & $105(11.6)$ \\
\hline Others & c & $4(6.2)$ & $40(61.5)$ & $15(23.1)$ & $6(9.2)$ & $65(7.2)$ \\
\hline Total & & $56(6.1)$ & $462(49.4)$ & $368(43)$ & $13(1.4)$ & $899^{\mathrm{b}}$ \\
\hline
\end{tabular}

COVID-19 core symptoms: fever, cough, dyspnoea, myalgia, headache, anosmia and dysgeusia

${ }^{a}$ Number of cases and row proportion between brackets are reported

b 894 total cases ( 5 cases presented two concomitant patterns)

c Seven erythema multiforme pattern, eight generalized pruritus, four herpes zoster, one herpes simplex virus-1 (HSV-1=, three Kawasaki disease, one pityriasis rosea-like, one atypical erythema nodosum, one bullae non-haemorrhagic, four Raynaud's phenomenon, nine dry gangrene with arteriosclerosis, six severe micro-circulatory ischaemia with preserve pulse, two palmar/acral erythaema, one leucocytoclastic vasculitis, two acute generalized exanthematous pustulosis (AGEP), one Stevens-Johnson syndrome, one urticarial vasculitis, two pressure-induced ischaemic necrosis in prolonged coma patient, one haematoma, one lichen planus, two contact dermatitis, one psoriasis, one generalized fixed drug eruption, one benign familial pemphigus, one chronic graft-versus-host disease, one stasis dermatitis, one dermatophytosis and one eruptive cherry angioma 


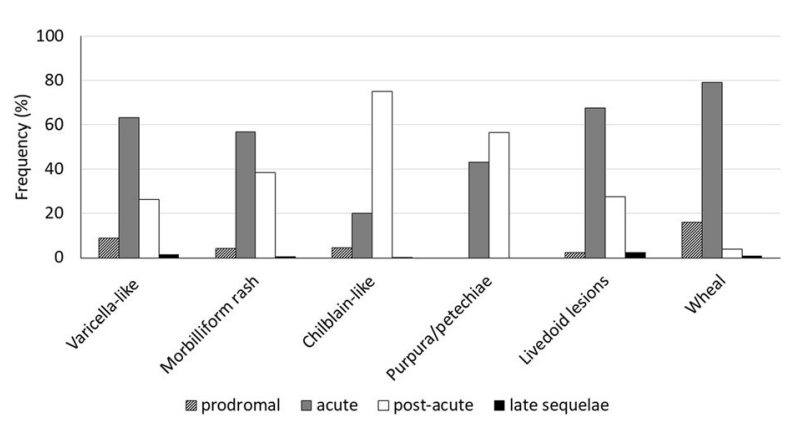

Fig. 3 Histograms reporting the frequency of COVID-19 associated skin lesions classified as prodromal (before COVID-19 onset), acute (within 2 weeks of COVID-19 onset), post-acute (from week 2 to 4 ) or late (after week 4 )

from the COVID-19 onset $(n=831,92 \%)$, whereas prodromal or late lesions were rarer $(n=69,8 \%)$. The time of onset of the skin lesions differed among the patterns. In particular, the urticarial and exanthema patterns, both varicella-like and morbilliform rush, were more frequent in the acute phase of the infection (within 2 weeks) (Fig. 3). In papers reporting varicella-like lesions, the diagnosis was based either on clinical examination only or after exclusion of true chickenpox by serology [68] or polymerase chain reaction (PCR) analysis of vesicle fluid $[34,54,61]$ or histologic examination $[10,40,58]$. About the vascular pattern some differences were noted among its subtypes. In detail, livedoid lesions were predominantly in the acute phase, while the chilblain subtype was more frequent in the post-acute phase (between week 2 and 4). The vascular purpuric/petechial subtype was equally distributed between the acute and post-acute phase. Several skin manifestations reported as associated with COVID-19 did not fall into the pattern classification, including erythema multiforme $(n=7)$, generalized pruritus $(n=8)$, herpes zoster $(n=4)$, HSV-1 virus infection $(n=1)$, Kawasaki disease $(n=3)$, pityriasis rosea-like $(n=1)$, atypical erythema nodosum $(n=1)$, bullae non-haemorrhagic $(n=1)$, Raynaud's phenomenon $(n=4)$, dry gangrene with arteriosclerosis $(n=9)$, severe micro-circulatory ischaemia with preserve pulse $(n=6)$, palmar/ acral erythema $(n=2)$, leucocytoclastic vasculitis $(n=2)$, AGEP $(n=2)$, Stevens-Johnson syndrome $(n=1)$, urticarial vasculitis $(n=1)$, pressure-induced ischaemic necrosis in prolonged coma patient $(n=2)$, haematoma $(n=1)$, lichen planus $(n=1)$, contact dermatitis $(n=2)$, psoriasis $(n=1)$, generalized fixed drug eruption $(n=1)$, benign familial pemphigus $(n=1)$, chronic graft-versus-host disease $(n=1)$, stasis dermatitis $(n=1)$, dermatophytosis $(n=1)$ and eruptive cherry angioma $(n=1)$.

\section{DISCUSSION}

We classified the time of onset of selected skin lesions associated with COVID-19 according to the framework proposed by Datta et al., who described the acute, post-acute and late phase of SARS-CoV-2 infection [3]. We have additionally considered a prodromal phase because skin lesions have been reported as the first and occasionally the only symptom of SARS-CoV-2 infection [12, 44, 96, 97]. The main finding of the study is that skin lesions occur more frequently in the first 4 weeks from the onset of the reported onset of the COVID-19 core symptoms. We acknowledge that the low number of cutaneous manifestations reported in the late phases could be interpreted as a report bias [98]. Indeed, late sequelae of SARSCoV-2 infection will be likely reported more extensively in the future [99]. Our findings provide new information to the framework proposed by Datta et al. in which cutaneous manifestations were considered only in the post-acute phase, whereas we found that urticarial and exanthema patterns are more frequently reported in the acute phase of the infection [3]. Moreover, we found that the time of onset of individual patterns is different. Urticarial and exanthema patterns were more frequent in the acute phase, whereas the vascular pattern showed some differences among its subtypes. Livedoid lesions were predominantly in the acute phase, while chilblain-like lesions were more frequent in the post-acute phase. The diversity in the time of onset of skin lesions as well as their polymorphic nature likely reflects the diversity of the pathogenetic underlying mechanisms [100]. Exanthema may result from the haematogenous spreading of the virus through the cutaneous vascular system 
and the immunologic reaction to viral particles [101]. Urticarial lesions may reflect the cutaneous expression of angiotensin-converting enzyme 2 as well as the direct stimulation of mast cell degranulation via complement activation [102]. Purpuric and livedoid lesions reflect a complement mediated endothelial injury [103]. The chilblain-like lesions are considered secondary to a delayed immune-mediated response involving the small cutaneous capillaries [104]. Several other muco-cutaneous manifestations that did not fall into the pattern classification have been reported, but we do not have solid arguments to classify them as incidental or linked to COVID-19, because pathogenetic studies are needed. SARS-CoV-2 infection is a complex disease that can favour different types of immunological disorders through various mechanisms that need to be elucidated.

We acknowledge the limitations of our study. Firstly, we have not considered all the muco-cutaneous manifestations associated with COVID-19 reported in literature, but we have selected a priori only a few of them that were the most frequent. We have collected information about their time of onset with respect to the reported onset of the COVID-19 core symptoms, not considering their overall duration, which is, however, poorly reported. The criterion for defining the onset of COVID-19 was not uniform among the articles, and we had to exclude those not clearly detailing the time of onset of skin lesions. Some skin lesions such as chilblain-like lesions were easily identified in the literature review, while others such as livedoid or purpuric lesions may have been overlapping. We were not able to make any inferential statistics on the data collected.

\section{CONCLUSIONS}

In conclusion, the diversity in the time of onset of skin lesions associated with COVD-19 as well as their polymorphic nature likely reflects the diversity of the pathogenetic underlying mechanisms. Finally, some proposals for future research may be suggested, including the definition of diagnostic criteria for COVID19 onset of COVID-19 infection, the identification of time of onset and duration of the different extrapulmonary manifestations associated with SARS-CoV-2 infection as well as their pathophysiological mechanisms and specific therapeutic approach.

\section{ACKNOWLEDGEMENTS}

Funding. No funding or sponsorship was received for this study or publication of this article.

Authorship. All named authors meet the International Committee of Medical Journal Editors (ICMJE) criteria for authorship for this article, take responsibility for the integrity of the work as a whole, and have given their approval for this version to be published.

Authorship contributions. Gisondi Paolo, Di Leo Sara, Bellinato Francesco, Cazzaniga Simone, Piaserico Stefano, Naldi Luigi contributed equally to concept and design of the study. Bellinato Francesco, Di Leo Sara and Cazzaniga Simone performed the statistical analysis. Gisondi Paolo, Di Leo Sara, Bellinato Francesco, Cazzaniga Simone, Piaserico Stefano, Naldi Luigi contributed to draft and revise the manuscript.

Disclosures. Gisondi Paolo, Di Leo Sara, Bellinato Francesco, Cazzaniga Simone, Piaserico Stefano, Naldi Luigi have no conflicts of interest to declare.

Compliance with Ethics Guidelines. This article is based on previously conducted studies and does not contain any studies with human participants or animals performed by any of the authors. This research has been conducted in accordance with the Helsinki Declaration. The participants provided consent for the images to be used in this publication.

Data availability. Data are available in the Tables and supplementary Tables attached. 
Open Access. This article is licensed under a Creative Commons Attribution-NonCommercial 4.0 International License, which permits any non-commercial use, sharing, adaptation, distribution and reproduction in any medium or format, as long as you give appropriate credit to the original author(s) and the source, provide a link to the Creative Commons licence, and indicate if changes were made. The images or other third party material in this article are included in the article's Creative Commons licence, unless indicated otherwise in a credit line to the material. If material is not included in the article's Creative Commons licence and your intended use is not permitted by statutory regulation or exceeds the permitted use, you will need to obtain permission directly from the copyright holder. To view a copy of this licence, visit http://creativecommons.org/licenses/by$\mathrm{nc} / 4.0 /$.

\section{REFERENCES}

1. Thakur V, Ratho RK, Kumar P, et al. Multi-organ involvement in COVID-19: beyond pulmonary manifestations. J Clin Med. 2021;10(3):446.

2. Tan SW, Tam YC, Oh CC. Skin manifestations of COVID-19: a worldwide review. JAAD Int. 2021;2: 119-33.

3. Datta SD, Talwar A, Lee JT. A proposed framework and timeline of the spectrum of disease due to SARS-CoV-2 infection: illness beyond acute infection and public health implications: illness beyond acute infection and public health implications. JAMA. 2020;324(22):2251-2.

4. Guan W-J, Ni Z-Y, Hu Y, et al. Clinical characteristics of coronavirus disease 2019 in China. N Engl J Med. 2020;382(18):1708-20.

5. Perna A, Passiatore M, Massaro A, et al. Skin manifestations in COVID-19 patients, state of the art. A systematic review. Int $\mathrm{J}$ Dermatol (Internet). 2021;(ijd.15414). $\quad$ https://doi.org/10.1111/ijd. 15414.

6. Gisondi P, PIaserico S, Bordin C, Alaibac M, Girolomoni G, Naldi L. Cutaneous manifestations of SARS-CoV-2 infection: a clinical update. J Eur Acad Dermatol Venereol. 2020;34(11):2499-504.
7. Moher D, Liberati A, Tetzlaff J, Altman DG, PRISMA Group. Preferred reporting items for systematic reviews and meta-analyses: the PRISMA statement. Int J Surg. 2010;8(5):336-41.

8. Murad MH, Sultan S, Haffar S, Bazerbachi F. Methodological quality and synthesis of case series and case reports. BMJ Evid Based Med. 2018;23(2): 60-3.

9. Ahouach B, Harent S, Ullmer A, et al. Cutaneous lesions in a patient with COVID-19: are they related? Br J Dermatol. 2020;183(2).

10. Almeida G, Arruda S, Marques E, Michalany N, Sadick N. Presentation and management of cutaneous manifestations of COVID-19. J Drugs Dermatol. 2021;20(1):76-83.

11. Alonso MN, Mata-Forte $\mathrm{T}$, García-León $\mathrm{N}$, et al. Incidence, characteristics, laboratory findings and outcomes in acro-ischemia in COVID-19 patients. Vasc Health Risk Manag. 2020;16:467-78.

12. Altayeb A, Cordaro A, Caesar J, Vyas J, Ingram J. Two cases of skin manifestations prior to the onset of COVID-19 respiratory symptoms. Int J Dermatol. 2020;59(12):1541-2.

13. Amatore F, Macagno N, Mailhe M, et al. SARS-CoV2 infection presenting as a febrile rash. J Eur Acad Dermatol Venereol. 2020;34(7).

14. Andina D, Colmenero I, Santonja C, et al. Suspected COVID-19-related reticulated purpura of the soles in an infant. Pediatr. Dermatol. (2020).

15. Annunziata M, Patrì A, Ruggiero A, et al. Cutaneous involvement during COVID-19 pandemic: an emerging sign of infection. J Eur Acad Dermatol Venereol. 2020;34(11).

16. Avellana Moreno R, Estela Villa L, Avellana Moreno V, Estela Villa C, Moreno Aparicio M, Avellana Fontanella J. Cutaneous manifestation of COVID-19 in images: a case report. J Eur Acad Dermatol Venereol. 2020;34(7).

17. Bouaziz J, Duong T, Jachiet M, et al. Vascular skin symptoms in COVID-19: a French observational study. J Eur Acad Dermatol Venereol. 2020;34(9).

18. Camprodon Gómez M, González-Cruz C, Ferrer B, Barberá M. Leucocytoclastic vasculitis in a patient with COVID-19 with positive SARS-CoV-2 PCR in skin biopsy. BMJ Case Rep. 2020;13(10):e238039.

19. Chaabane I, Loukil M, Amri R, et al. Cutaneous manifestations of COVID-19: report of three cases. Arch Dermatol Res. (2020). 
20. Chen V, Escandon Brehm J, Bellodi Schmidt F. Acute urticaria preceding other COVID-19-associated manifestations - a case report. Pediatr. Dermatol. (2021).

21. Conforti C, Zalaudek I, Giuffrida R, et al. " COVIDMask ": an atypical livedoid manifestation of COVID-19 observed in a Northern Italy hospital. Dermatol. Ther. 2020;33(4).

22. Dalal A, Jakhar D, Agarwal V, Beniwal R. Dermatological findings in SARS-CoV-2 positive patients: An observational study from North India. Dermatol. Ther. 2020;33(6).

23. de Lorenzo Alvarez A, Revilla Á, Corbalán T, et al. Ischemic stroke and purpuric dermatitis as COVID19-related complications in a peritoneal dialysis patient. CEN Case Rep. 2020.

24. de Medeiros V, Silva L. Follow-up of skin lesions during the evolution of COVID-19: a case report. Arch. Dermatol. Res. (2020).

25. Diaz-Guimaraens B, Dominguez-Santas M, SuarezValle A, et al. Petechial skin rash associated with severe acute respiratory syndrome coronavirus 2 infection. JAMA Dermatol. 2020;156(7):820-2.

26. Docampo-Simón A, Sánchez-Pujol MJ, GimenoGascon A, et al. No SARS-CoV-2 antibody response in 25 patients with pseudo-chilblains. Dermatol Ther. 2020;33(6):e14332.

27. Dominguez-Santas M, Diaz-Guimaraens B, Garcia Abellas P, Moreno-Garcia Del Real C, Burgos-Blasco $\mathrm{P}$, Suarez-Valle A. Cutaneous small-vessel vasculitis associated with novel 2019 coronavirus SARS-CoV-2 infection (COVID-19). J Eur Acad Dermatol Venereol. 2020;34(10):e536-7.

28. Droesch C, Do MH, DeSancho M, Lee E-J, Magro C, Harp J. Livedoid and purpuric skin eruptions associated with coagulopathy in severe COVID-19. JAMA Dermatol. 2020;156(9):1-3.

29. Elsaie ML, Nada HA. Herpes zoster (shingles) complicating the course of COVID19 infection. J Dermatol Treat. 2020;1-3.

30. Elsaie ML, Youssef EA, Nada HA. Herpes zoster might be an indicator for latent COVID 19 infection. Dermatol Ther. 2020;33(4):e13666.

31. Falkenhain-López D, Sánchez-Velázquez A, LópezValle A, Ortiz-Frutos FJ. SARS-coronavirus-2 and acute urticaria. Int J Dermatol. 2020;59(7):867-8.

32. Fattori A, Cribier B, Chenard M-P, Mitcov M, Mayeur S, Weingertner N. Cutaneous manifestations in patients with coronavirus disease 2019: clinical and histological findings. Hum Pathol. 2021;107:39-45.

33. Feito-Rodríguez M, Mayor-Ibarguren A, CámaraHijón C, et al. Chilblain-like lesions and COVID-19 infection: a prospective observational study at Spain's ground zero. J Am Acad Dermatol. 2021;84(2):507-9.

34. Fernandez-Nieto D, Ortega-Quijano D, JimenezCauhe J, et al. Clinical and histological characterization of vesicular COVID-19 rashes: a prospective study in a tertiary care hospital. Clin Exp Dermatol. 2020;45(7):872-5.

35. Fernandez-Nieto D, Ortega-Quijano D, SeguradoMiravalles G, Pindado-Ortega C, Prieto-Barrios M, Jimenez-Cauhe J. Comment on: Cutaneous manifestations in COVID-19: a first perspective. Safety concerns of clinical images and skin biopsies. J Eur Acad Dermatol Venereol. 2020;34(6):e252-4.

36. Fertitta L, Welfringer-Morin A, Ouedrani A, et al. Immunological and virological profile of children with chilblain-like lesions and SARS-CoV-2. J Eur Acad Dermatol Venereol [Internet]. 2020;(jdv. 16972). https://pubmed.ncbi.nlm.nih.gov/ $33010072 /$.

37. Galván Casas C, Català A, Carretero Hernández G, et al. Classification of the cutaneous manifestations of COVID-19: a rapid prospective nationwide consensus study in Spain with 375 cases. Br J Dermatol. 2020;183(1):71-7.

38. Genovese G, Colonna C, Marzano AV. Varicella-like exanthem associated with COVID-19 in an 8-yearold girl: a diagnostic clue? Pediatr Dermatol. 2020;37(3):435-6.

39. Gianotti R, Veraldi S, Recalcati S, et al. Cutaneous clinico-pathological findings in three COVID-19positive patients observed in the metropolitan area of Milan, Italy. Acta Derm Venereol. 2020;100(8): adv00124.

40. Giavedoni P, Podlipnik S, Pericàs JM, et al. Skin manifestations in COVID-19: prevalence and relationship with disease severity. J Clin Med [Internet]. 2020;9(10). https://www.mdpi.com/resolver?pii= jcm9103261.

41. Sousa Gonçalves C, Reis Carreira N, Passos D, et al. Erythematous papular rash: a dermatological feature of COVID-19. Eur J Case Rep Intern Med. 2020;7(7):001768.

42. Goyal S, Prabhu S, U S, Pai SB, Mohammed A. Cutaneous manifestations of COVID-19 in skin of color: a firsthand perspective of three cases in a tertiary care center in India. Postgrad Med. 2020;(00325481.2020.1852784):1-3. 
43. Gunawan C, Angela A, Widysanto A. Urticarial eruption in coronavirus disease 2019 infection: a case report in Tangerang. Indonesia $\mathrm{J}$ Eur Acad Dermatol Venereol. 2020;34(8):e372-3.

44. Hassan K. Urticaria and angioedema as a prodromal cutaneous manifestation of SARS-CoV-2 (COVID19) infection. BMJ Case Rep. 2020;13(7):e236981.

45. Hedou M, Carsuzaa F, Chary E, Hainaut E, Cazenave-Roblot F, Masson RM. Comment on "Cutaneous manifestations in COVID-19: a first perspective" by Recalcati S. J Eur Acad Dermatol Venereol. 2020;34(7):e299-300.

46. Henry D, Ackerman M, Sancelme E, Finon A, Esteve E. Urticarial eruption in COVID-19 infection. J Eur Acad Dermatol Venereol. 2020;34(6):e244-5.

47. Hubiche T, Cardot-Leccia N, Le Duff F, et al. Clinical, laboratory, and interferon-alpha response characteristics of patients with chilblain-like lesions during the COVID-19 pandemic. JAMA Dermatol [Internet]. 2020. https://doi.org/10.1001/ jamadermatol.2020.4324.

48. Hunt M, Koziatek C. A case of COVID-19 pneumonia in a young male with full body rash as a presenting symptom. Clin Pract Cases Emerg Med. 2020;4(2):219-21.

49. Iancu GM, Solomon A, Birlutiu V. Viral exanthema as manifestation of SARS-CoV-2 infection: a case report: a case report. Medicine (Baltimore). 2020;99(35):e21810.

50. Jimenez-Cauhe J, Ortega-Quijano D, Carretero-Barrio I, et al. Erythema multiforme-like eruption in patients with COVID-19 infection: clinical and histological findings. Clin Exp Dermatol. 2020;45(7):892-5.

51. Jones VG, Mills M, Suarez D, et al. COVID-19 and Kawasaki disease: novel virus and novel case. Hosp Pediatr. 2020;10(6):537-40.

52. Joob B, Wiwanitkit V. COVID-19 can present with a rash and be mistaken for dengue. J Am Acad Dermatol. 2020;82(5):e177.

53. Kolivras A, Dehavay F, Delplace D, et al. Coronavirus (COVID-19) infection-induced chilblains: a case report with histopathologic findings. JAAD Case Rep. 2020;6(6):489-92.

54. Llamas-Velasco M, Rodríguez-Jiménez $\mathrm{P}$, Chicharro P, De Argila D, Muñoz-Hernández P, Daudén E. Reply to "Varicella-like exanthem as a specific COVID-19-associated skin manifestation: multicenter case series of 22 patients": to consider varicella-like exanthem associated with COVID-19, virus varicella zoster and virus herpes simplex must be ruled out. J Am Acad Dermatol. 2020;83(3): e253-4.

55. Locatelli AG, Robustelli Test E, Vezzoli P, et al. Histologic features of long-lasting chilblain-like lesions in a paediatric COVID-19 patient. J Eur Acad Dermatol Venereol. 2020;34(8):e365-8.

56. Macedo-Pérez M, Barragán-Estudillo ZF, CastilloMontufar E, et al. Dermatological findings in COVID-19 patients: Mexican experience. Int J Dermatol. 2020;59(7):872-3.

57. Mahé A, Birckel E, Krieger S, Merklen C, Bottlaender L. A distinctive skin rash associated with coronavirus disease 2019? J Eur Acad Dermatol Venereol. 2020;34(6):e246-7.

58. Marzano AV, Genovese G, Fabbrocini G, et al. Varicella-like exanthem as a specific COVID-19-associated skin manifestation: multicenter case series of 22 patients. J Am Acad Dermatol. 2020;83(1): 280-5.

59. Marzano AV, Genovese G, Moltrasio C, et al. The clinical spectrum of COVID-19-associated cutaneous manifestations: an Italian multicentre study of 200 adult patients. J Am Acad Dermatol [Internet]. 2021; https://doi.org/10.1016/j.jaad.2021.01. 023.

60. Mascitti H, Bonsang B, Dinh A, et al. Clinical cutaneous features of patients infected with SARS-CoV-2 hospitalized for pneumonia: a cross-sectional study. Open Forum Infect Dis. 2020;7(11):ofaa394.

61. Méndez Maestro I, Peña Merino L, Tánago UGD, et al. Skin manifestations in patients hospitalized with confirmed COVID-19 disease: a cross-sectional study in a tertiary hospital. Int J Dermatol. 2020;59(11):1353-7.

62. Micevic G, Morris J, Lee AI, King BA. Perniolike lesions and coagulopathy in a patient with COVID19 infection. JAAD Case Rep. 2020;6(12):1294-6.

63. Morey-Olivé M, Espiau M, Mercadal-Hally M, LeraCarballo E, García-Patos V. Cutaneous manifestations in the current pandemic of coronavirus infection disease (COVID 2019). An Pediatr (Engl Ed). 2020;92(6):374-5.

64. Najarian DJ. Morbilliform exanthem associated with COVID-19. JAAD Case Rep. 2020;6(6):493-4.

65. Navaeifar MR, Poudineh Ghazaghi M, Shahbaznejad L, et al. Fever with rash is one of the first presentations of COVID-19 in children: a case report. Int Med Case Rep J. 2020;13:335-40.

66. Negrini S, Guadagno A, Greco M, Parodi A, Burlando M. An unusual case of bullous haemorrhagic 
vasculitis in a COVID-19 patient. J Eur Acad Dermatol Venereol. 2020;34(11):e675-6. https://doi. org/10.1111/jdv.16760 ((epub 2020 Jul 6)).

67. Öksüm Solak E, Baran Ketencioğlu B, Çinar SL, Kartal D, Borlu M. Coronavirus disease 2019 (COVID-19) accompanied by maculopapular rash: a case study. Cureus. 2020;12(9):e10414.

68. Oliva Rodríguez-Pastor S, Martín Pedraz L, Carazo Gallego B, et al. Skin manifestations during the COVID-19 pandemic in the pediatric Emergency Department. Pediatr Int [Internet]. 2020;(ped. 14568). https://doi.org/10.1111/ped.14568.

69. Olisova OY, Anpilogova EM, Shnakhova LM. Cutaneous manifestations in COVID-19: a skin rash in a child. Dermatol Ther. 2020;33(6):e13712.

70. Panambur B, Kakkilaya SB. Palmar erythema as the sole manifestation of COVID-19. Cureus. 2020;12(11):e11291.

71. Patel N, Kho J, Smith KE, et al. Polymorphic cutaneous manifestations of COVID-19 infection in a single viral host. Int J Dermatol. 2020;59(9): 1149-50.

72. Pavone P, Marino S, Marino L, et al. Chilblains-like lesions and SARS-CoV-2 in children: an overview in therapeutic approach. Dermatol Ther. 2020;e14502.

73. Punyaratabandhu P, Chirachanakul P. Cutaneous eruption in COVID-19-infected patients in Thailand: an observational descriptive study. J Dermatol. 2021;48(1):14-20.

74. Quintana-Castanedo L, Feito-Rodríguez M, ValeroLópez I, Chiloeches-Fernández C, SendagortaCudós E, Herranz-Pinto P. Urticarial exanthem as early diagnostic clue for COVID-19 infection. JAAD Case Rep. 2020;6(6):498-9.

75. Rafai M, Elbenaye J, Sabry S, Janah H. Delayed hypersensitivity as a pathophysiological mechanism in cutaneous lesions due to SARS-CoV-2. Pan Afr Med J [Internet]. 2020;35. https://doi.org/10. 11604/pamj.supp.2020.35.2.24980.

76. Rivera-Oyola R, Koschitzky M, Printy R, et al. Dermatologic findings in 2 patients with COVID-19. JAAD Case Rep. 2020;6(6):537-9.

77. Rossi E, Lasagni C, Trakatelli M, Wertzberger Rowan $\mathrm{S}$, Magnoni C. Acute maculopapular eruption in Covid-19 patient: a case report. Dermatol Ther. 2020;33(6):e13812.

78. Rotman JA, Dean KE, Magro C, Nuovo G, Bartolotta RJ. Concomitant calciphylaxis and COVID-19 associated thrombotic retiform purpura. Skelet Radiol. 2020;49(11):1879-84.
79. Rotulo GA, Signa S, Rosina S, Pastorino C, Bondi E, Maghnie M. Giant urticaria and acral peeling in a child with coronavirus disease 2019. J Pediatr [Internet]. 2020; https://doi.org/10.1016/j.jpeds.2020. 10.039 .

80. Rubin A, Alamgir M, Rubin J, Rao BK. Chilblain-like lesions with prominent bullae in a patient with COVID-19. BMJ Case Rep. 2020;13(11):e237917.

81. Sachdeva M, Gianotti R, Shah M, et al. Cutaneous manifestations of COVID-19: report of three cases and a review of literature. J Dermatol Sci. 2020;98(2):75-81.

82. Sakaida T, Tanimoto I, Matsubara A, Nakamura M, Morita A. Unique skin manifestations of COVID-19: is drug eruption specific to COVID-19? J Dermatol Sci. 2020;99(1):62-4.

83. Sanchez A, Sohier P, Benghanem S, et al. Digitate papulosquamous eruption associated with severe acute respiratory syndrome coronavirus 2 infection. JAMA Dermatol. 2020;156(7):819-20.

84. Serafini A, Kurotschka PK, Bertolani M, Riccomi S. An itchy erythematous papular skin rash as a possible early sign of COVID-19: a case report. J Med Case Rep. 2020;14(1):216.

85. Spencer R, Closson RC, Gorelik M, et al. COVID-19 inflammatory syndrome with clinical features resembling Kawasaki disease. Pediatrics. 2020;146(3):e20201845.

86. Suarez-Valle A, Fernandez-Nieto D, Diaz-Guimaraens B, Dominguez-Santas M, Carretero I, PerezGarcia B. Acro-ischaemia in hospitalized COVID-19 patients. J Eur Acad Dermatol Venereol. 2020;34(9): e455-7.

87. Suter P, Mooser B, Pham Huu Thien HP. Erythema nodosum as a cutaneous manifestation of COVID19 infection. BMJ Case Rep. 2020;13(7):e236613.

88. Tahir A, Sohail Z, Nasim B, Parmar NV. Widespread cutaneous small vessel vasculitis secondary to COVID-19 infection. Int J Dermatol. 2020;59(10): 1278-9.

89. Tamai M, Maekawa A, Goto N, et al. Three cases of COVID-19 patients presenting with erythema. J Dermatol. 2020;47(10):1175-8.

90. van Damme C, Berlingin E, Saussez S, Accaputo O. Acute urticaria with pyrexia as the first manifestations of a COVID-19 infection. J Eur Acad Dermatol Venereol. 2020;34(7):e300-1.

91. Vanaparthy R, Malayala SV, Balla M. COVID-19induced vestibular neuritis, hemi-facial spasms and 
Raynaud's phenomenon: a case report. Cureus. 2020;12(11):e11752.

92. Widysanto A, Wahyuni TD, Simanjuntak LH, et al. Ecchymosis in critical coronavirus disease 2019 (COVID-19) patient in Tangerang, Indonesia: a case report. J Thromb Thrombolysis [Internet]. 2020; https://doi.org/10.1007/s11239-020-02338-7.

93. Young S, Fernandez AP. Skin manifestations of COVID-19. Cleve Clin J Med [Internet]. 2020; https://doi.org/10.3949/ccjm.87a.ccc031.

94. Zengarini C, Orioni G, Cascavilla A, et al. Histological pattern in COVID-19-induced viral rash. J Eur Acad Dermatol Venereol. 2020;34(9):e453-4.

95. Zinder R, Andrews C, Cristallo J, Flattau A. COVID19 wounds: unusual lower extremity bullae. Int J Low Extrem Wounds. 2020;1534734620964284.

96. Li H, Zhao Y, Zhou L, Hu J. Cutaneous, skin histopathological manifestations and relationship to COVID-19 infection patients. Dermatol Ther. 2020;33(6):e14157.

97. Visconti A, Bataille V, Rossi N, et al. Diagnostic value of cutaneous manifestation of SARS-CoV-2 infection. $\mathrm{Br} \mathrm{J}$ Dermatol [Internet]. 2021;(bjd. 19807). https://doi.org/10.1111/bjd.19807.

98. Freeman EE, McMahon DE, Fitzgerald ME, et al. The American Academy of Dermatology COVID-19 registry: Crowdsourcing
99. Brazzelli V, Vassallo C, Barruscotti S, et al. Late-onset cutaneous eruption in hospitalized COVID-19 patients. Eur J Dermatol. 2020;30(5):621-2.

100. Hu B, Guo H, Zhou P, Shi Z-L. Characteristics of SARS-CoV-2 and COVID-19. Nat Rev Microbiol. 2021;19(3):141-54.

101. Gianotti R, Recalcati S, Fantini F, et al. Histopathological study of a broad spectrum of skin dermatoses in patients affected or highly suspected of infection by COVID-19 in the northern part of Italy: analysis of the many faces of the viral-induced skin diseases in previous and new reported cases. Am J Dermatopathol. 2020;42(8):564-70.

102. Allegra A, Asero R, Giovannetti A, Isola S, Gangemi S. Urticaria and coronavirus infection: a lesson from SARS-CoV-2 pandemic. Eur Ann Allergy Clin Immunol [Internet]. 2020;(online first). https://doi. org/10.23822/EurAnnACI.1764-1489.173.

103. Magro C, Mulvey JJ, Berlin D, et al. Complement associated microvascular injury and thrombosis in the pathogenesis of severe COVID-19 infection: a report of five cases. Transl Res. 2020;220:1-13.

104. Recalcati S, Barbagallo T, Frasin LA, et al. Acral cutaneous lesions in the time of COVID-19. J Eur Acad Dermatol Venereol. 2020;34(8):e346-7. 